\title{
Integrasi SIG dan Penginderaan Jauh Untuk Pemetaan Tingkat Kerawanan Kebakaran Lahan di Lampung Utara
}

\author{
Taufiq Feriansyah ${ }^{1}{ }^{*}$, Rindy Febriani ${ }^{1}$, Wayan Vinna Elvira ${ }^{1}$, Pitry Dwiatika Norcela ${ }^{1}$, \\ Retno Gayatri ${ }^{1}$, Ryas Hary', Sarah Safira Muchliana', Nurul Nahar ${ }^{2}$ \\ ${ }^{1}$ Jurusan Teknik Geofisika, Fakultas Teknik, Universitas Lampung, Jl. Prof. Dr. Ir. Sumantri Brojonegoro, Bandar Lampung, \\ Lampung 35141 \\ ${ }^{2}$ Jurusan Teknik Geologi, UPN Veteran Yogyakarta, JI. SWK Ring Road Utara No. 104, Condong Catur, Depok, Sleman 55283
}

Dikirim:
15 April 2020
Direvisi:
15 Mei 2020
Diterima:
17 Juni 2020
*Email Korespondensi:
taufigferiash@gmail.com
(0) (i) (9)

Abstract: Forest fires are one form of disturbance that is increasingly common. The significant negative impacts caused by forest fires include ecological damage, declining biodiversity, declining economic value of forests and soil productivity, micro and global climate change, and smoke disturbing public health and disrupting transportation both land, rivers, lakes, oceans and air. In general, the method used to conduct research on forest and land fire vulnerability consists of 7 parameters, namely rainfall, temperature, road accessibility, river accessibility, temporal hotspot density in 2019, land cover / use, and land use. The weighting process will then be performed using the Weighted Overlay feature with an assessment of the influence and welding of each parameter. In this research, tools and materials are used, namely ArcGis software, Landsat 8 imagery, and RBI data. From the results of the overlay carried out on 7 parameters, a fire hazard map was produced, with classes that were not vulnerable, moderate, and very vulnerable.

Keywords: GIS, land fires, map, North Lampung, remote sensing
Abstrak: : Kebakaran hutan merupakan salah satu bentuk gangguan yang makin mencakup kerusakan ekologis, menurunnya keanekaragaman hayati, merosotnya nilai ekonomi hutan dan produktivitas tanah, perubahan iklim mikro maupun global, dan sapha mengganggu kesehatan masyarakat serta mengganggu transportasi baik sungai, danau, laut dan udara. Secara umum metode yang digunakan untuk yaitu curah hujan, suhu, aksesibilitas jalan, aksesibilitas sungai, kepadatan hotspot mporal tahun 2019, tutupan/penggunaan lahan, dan peruntukan lahan. Yang dengan penilaian influen dan pengkelasan masing-masing parameter. Pada penelitian ini digunakan alat dan bahan yaitu software ArcGIS, citra Landsat 8, dan data RBI. Dari hasil overlay yang dilakukan pada 7 parameter, dihasilkan peta kerawanan kebakaran telas tidak rawan, sedang, dan sangat rawan. Dengan didapatkannya peta kerawanan kebakaran hutan dan lahan ini akan dapat diketahui masing-masing kerawanan kebakaran wilayah ataupun lahan.

Kata Kunci: kebakaran lahan, Lampung Utara, penginderaan jauh, peta, SIG

\section{PENDAHULUAN}

Sejak tahun 1997 hingga saat ini, kebakaran hutan dan lahan (karhutla) di Indonesia terjadi hampir setiap tahun. Kejadian karhutla tahun 2015 diduga telah membakar hutan dan lahan seluas 3,61 juta hektar (BNPB, 2016). Ditahun 2016, meski Indonesia dilanda El Nina, karhutla tetap terjadi yang membakar hutan dan lahan seluas 14604,84 hektar (KLHK, 2016). Kebakaran hutan dan lahan memberikan dampak kerugian bagi lingkungan, sosial, dan ekonomi. Bahkan persoalan kebakaran di Indonesia telah mengakibatkan persoalan asap bagi negara tetangga khususnya di wilayah Asia Tenggara (Heil dkk., 2007).

Kebakaran disebabkan oleh dua faktor utama, yaitu kebakaran didukung oleh pemanasan global, kemarau ekstrem yang sering kali dikaitkan dengan pengaruh iklim yang memberikan kondisi ideal untuk terjadinya kebakaran hutan dan aktivitas manusia dalam pengolahan lahan (Suhendri, 2017). Menurut Danny (2001), penyebab utama terjadinya kebakaran hutan di Kalimantan Timur adalah karena aktivitas manusia dan hanya sebagian kecil yang disebabkan oleh kejadian alam. Kebakaran karena proses alam tersebut sangat kecil dan untuk kasus Kalimantan kurang dari $1 \%$.

Identifikasi faktor penyebab kebakaran merupakan unsur yang sangat penting dalam kegiatan pengendalian kebakaran, karena dalam sejarah tersebut akan dapat diketahui asal usul dan penyebab terjadinya kebakaran. Tanpa diketahuinya penyebab kebakaran hutan dengan pasti, maka kegiatan pengendalian kebakaran hutan tidak akan dapat dilaksanakan secara optimal. Diharapkan dengan penelitian ini dapat menghasilkan peta kerawanan kebakaran lahan untuk menentukan kategori kerawanan kebakaran untuk daerah Lampung Utara agar dapat digunakan sebagai dasar untuk penelitian dan pengembangan lebih lanjut. 


\section{BAHAN DAN METODE PENELITIAN}

Penelitian ini dilakukan pada tahun 2019 dengan daerah penelitian yaitu Kabupaten Lampung Utara. Pada penelitian ini dilakukan pembuatan peta kerawanan kebakaran hutan dan lahan yang terdiri dari 7 parameter yaitu curah hujan, suhu, aksesibilitas jalan, aksesibilitas sungai, kepadatan hotspot temporal tahun 2019, tutupan/penggunaan lahan, dan peruntukan lahan. Kemudian 7 parameter tersebut akan dilakukan proses pembobotan menggunakan fitur Weighted Overlay dengan penilaian influen dan pengkelasan masing-masing parameter. Pada penelitian ini digunakan alat dan bahan yaitu software ArcGIS, citra Landsat 8, data USGS Portal, dan data RBI. Secara lebih rinci akan dibahas sebagai berikut:

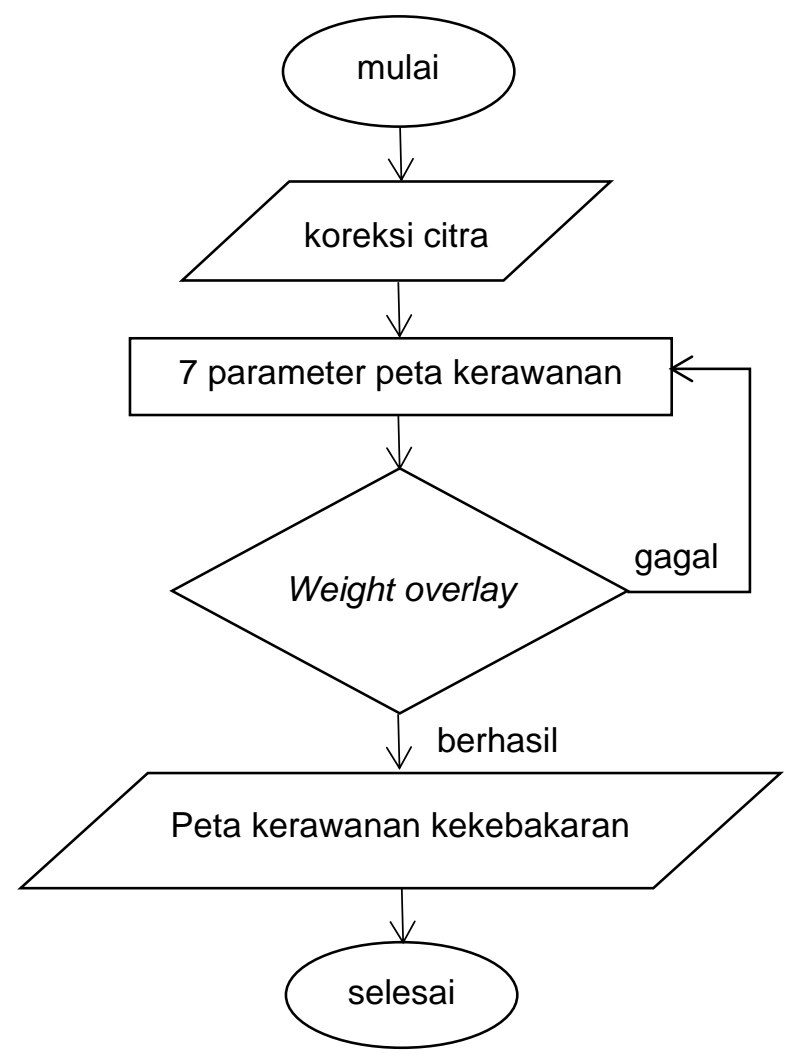

Gambar 1. Tahapan-tahapan yang dilakukan dalam penelitian ini

\subsection{Koreksi Citra}

1. Koreksi Radiometrik

Koreksi radiometrik pada penelitian kali ini ditujukan untuk mengurangi beberapa kesalahan pada citra. Selain itu juga digunakan untuk mengembalikan nilai digital atau digital number (DN) ke nilai pantulan citra tersebut untuk dilakukan pengolahan selanjutnya. Landsat 8 masih bernilai Digital Number DN) sehingga perlu diubah menjadi Top Of Atmosferic (TOA) Reflectance. Koreksi reflektan dilakukan melalui persamaan yang dikeluarkan oleh USGS (USGS 2015) untuk Landsat-8 OLI. Koreksi ini disebut dengan koreksi top of atmosphere reflectance:

$$
P_{\lambda}=M_{\rho} Q_{c a l}+A_{\rho}
$$

$P_{\lambda}=$ TOA reflection

$M_{\rho}=$ nilai rescalong factor multi band

$Q_{c a l}=$ nilai digital number

$A_{\rho} \quad=$ nilai additive rescaling factor

Koreksi radiometrik juga dilakukan pada saluran TIRS yang ada pada citra tersebut, seperti pada saluran OLI tujuan pada saluran TIRS ini adalah mengubah data digital number (DN) ke nilai radiansi yang di tangkap oleh sensor citra atau sering disebut dengan Top Of Atmosferic (TOA) Radiance, di mana konversinya dapat dihasilkan dengan formula sebagai berikut (USGS, 2015):

$$
L_{\lambda}=M_{L}+Q c a l+A L
$$

$L_{\lambda}=$ TOA radiance

$M_{L} \quad=$ nilai rescalong factor multi band

$Q_{\text {cal }}=$ nilai digital number

$A_{\rho} \quad=$ nilai additive rescaling factor

Setelah dilakukan koreksi TOA radiance kemudian dilakukan perhitungan untuk mendapatkan nilai Satellite Brightness Temperature, dengan rumus (USGS, 2015 dalam Delarizka, 2016):

$$
T=\frac{K 2}{L N\left(\frac{K 1}{L_{\lambda}}+1\right)}-272,15
$$

$$
\begin{aligned}
T= & \text { At satelite brightness temperature }(c) \\
L_{\lambda}= & \text { TOA Radiance } \\
K 1= & \text { band specific thermal conversion from } \\
& \text { metadata }
\end{aligned}
$$

Nilai brightness temperature dari masing-masing band 10 dan 11 ini selanjutnya dicari reratanya untuk mendapatkan nilai brightness temperature rata-rata yang selanjutnya digunakan untuk mengetahui suhu permukaan.

\section{Transformasi NDVI}

Transformasi NDVI digunakan sebagai turunan proporsi vegetasi untuk mendapatkan nilai Land Surface Emissivity dalam proses transformasi suhu, yang dilakukan dengan rumus (Tucker, 1979):

$$
N D V I=\frac{(N I R-R E D)}{N I R+R E D}
$$

$N I R=$ saluran inframerah dekat

RED = saluran merah

Setelah nilai NDVI didapatkan, kemudian NDVI diturunkan untuk mengetahui proporsi vegetasi untuk mendapatkan nilai emisivitas, yaitu dengan rumus :

$$
P V=\left(\frac{\text { NDVI-NDVImin }}{\text { NDVImax }- \text { NDVImin }}\right)
$$

PV = proporsi vegetasi

NDVImin = nilai NDVI terendah 
NDVImax $=$ nilai NDVI tertinggi

Tabel 1. Klasifikasi NDVI (Wahyunto dkk., 2014)

\begin{tabular}{cc}
\hline $\begin{array}{c}\text { Rentang } \\
\text { Klasifikasi }\end{array}$ & Kerapatan \\
\hline$-1<\mathrm{NDVI}<-0,03$ & $\begin{array}{c}\text { Lahan tidak } \\
\text { bervegetasi } \\
\text { Kehijauan sangat } \\
\text { rendah }\end{array}$ \\
$0,03<\mathrm{NDVI}<0,15$ & Kehijauan rendah \\
$0,15<\mathrm{NDVI}<0,25$ & Kehijauan sedang \\
$0,25<\mathrm{NDVI}<0,35$ & Kehijauan tinggi \\
$0,35<\mathrm{NDVI}<1$ & \\
\hline
\end{tabular}

3. Transformasi Suhu Permukaan

Nilai dari proporsi vegetasi ini kemudian dijadikan input untuk mengetahui land surface emissivity dengan rumus :

$$
L S E=0.004 p v+0.986
$$

Setelah nilai land surface emissivity didapatkan, dilakukan transformasi untuk mengetahui nilai suhu permukaan dengan rumus :

$$
L S T=\frac{B T}{1+\left(\lambda * \frac{B T}{\rho}\right) * \ln (e)}
$$

\section{Dengan}

$$
\begin{array}{ll}
L S E & =\text { Land surface temperature } \\
B T & =\text { brightness temperature } \\
\lambda & =\text { wavelenght of emmited radiance } \\
\rho & =h * c / s(14380 \mathrm{~m} K) \\
S & =\text { Boltzmann constant } \\
E \quad & =\text { emissitivity }
\end{array}
$$

\subsection{Membuat Peta Klasifikasi}

\section{Peta Jaringan Jalan}

Jaringan jalan merupakan salah satu parameter penting terhadap kerawanan kebakaran. Di mana dapat di asumsikan bahwa semakin jauh akses jalan maka semakin tinggi tingkat kerawanan kebakaran pada suatu lahan. Dan daerah yang jauh dari akses jalan dapat dikategorikan sebagai daerah jauh dari pemukiman. Pada peta aksesibilitas jalan ini digunakan fitur multiplering buffer pada ArcMap dengan klasifikasi yaitu:

Tabel 2. Klasifikasi Peta Jaringan Jalan

\begin{tabular}{ccc}
\hline No & $\begin{array}{c}\text { Klasifikasi Jarak } \\
(\mathrm{Km})\end{array}$ & Kelas \\
\hline 1 & $0-2$ & 1 \\
2 & $2-5$ & 2 \\
3 & $5-10$ & 3 \\
\hline
\end{tabular}

2. Peta Jaringan Sungai

Jaringan sungai merupakan parameter yang berpengaruh terhadap kerawanan kebakaran lahan. Di mana dapat diasumsikan bahwa semakin jauh suatu kawasan dengan sumber air/sungai maka tingkat kerawanan kebakaran akan semakin tinggi. Sehingga dalam hal ini keberadaan sungai sangat berpengaruh. Dalam pembuatan aksesibilitas sungai ini digunakan fitur muliplering buffer pada ArcMap, dengan klasifikasi:

Tabel 3. Klasifikasi Jaringan Sungai

\begin{tabular}{ccc}
\hline No & $\begin{array}{c}\text { Klasifikasi Jarak } \\
(\mathrm{Km})\end{array}$ & Kelas \\
\hline 1 & $0-2$ & 1 \\
2 & $2-5$ & 2 \\
3 & $5-10$ & 3 \\
\hline
\end{tabular}

\section{Tutupan/Penggunaan Lahan}

Penutup atau penggunaan lahan sangat berpengaruh terhadap terjadinya kebakaran. Pada pembuatan peta ini dilakukan klasifikasi secara manual dengan mengikuti acuan klasifikasi tutupan lahan Endarmiyati (2009), seperti pada tabel berikut:

Tabel 4. Klasifikasi kerawanan tutupan lahan

\begin{tabular}{ll}
\hline \multicolumn{1}{c}{ Penutup lahan } & Kelas \\
\hline $\begin{array}{l}\text { Hutan lahan kering sekunder, } \\
\text { landclearing HTI, landclearing } \\
\text { perkebunan }\end{array}$ & $\begin{array}{l}\text { Sangat } \\
\text { rawan }\end{array}$ \\
$\begin{array}{l}\text { Hutan mangrove sekunder, } \\
\text { hutan rawa sekunder, pertanian } \\
\text { lahan kering campur semak, } \\
\text { semak belukar/rawa, pertanian } \\
\text { lahan kering }\end{array}$ & \\
$\begin{array}{l}\text { Hutan tanaman, perkebunan, } \\
\text { pertanian lahan basah, pertam- } \\
\text { bangan, area terbuka, area ter- } \\
\text { bangun }\end{array}$ & Sedang \\
$\begin{array}{l}\text { Hutan lahan kering primer, hu- } \\
\text { tan rawa primer, hutan mang- } \\
\text { rove primer }\end{array}$ & \\
\end{tabular}

\section{Kepadatan Hotspot}

Kepadatan hotspot mempengaruhi tingkat kerawanan kebakaran suatu lahan. Di mana keterdapatan hotspot yang tinggi akan cenderung memiliki tingkat kerawanan kebakaran yang tinggi. Data hotspot temporal yang digunakan pada penelitian ini yaitu sepanjang tahun 2019 yang berasal dari data LAPAN Fire Hotspot. Pembuatan peta ini menggunakan fitur point density yang terdapat pada ArcMap, dengan kelas kerawanannya yaitu:

Tabel 4. Klasifikasi Kepadatan Hotspot

\begin{tabular}{ccc}
\hline No & Kelas & Klasifikasi \\
\hline 1 & 1 & Sangat Jarang \\
2 & 2 & Sedang
\end{tabular}




\begin{tabular}{ccc}
3 & 3 & Padat \\
4 & 4 & Sangat Padat \\
\hline
\end{tabular}

\section{Suhu Udara}

Suhu merupakan salah satu faktor yang mempengaruhi kebakaran hutan dan lahan. Di mana dapat diasumsikan ketika suatu kawasan memiliki suhu yang tinggi maka akan semakin tinggi tingkat kerawanan kebakaran. Pembuatan peta suhu permukaan ini digunakan data Landsat 8 , dengan pembagian 6 kelas yaitu:

Tabel 5. Klasifikasi Suhu Udara

\begin{tabular}{ccc}
\hline No & Kelas & $\begin{array}{c}\text { Klasifikasi } \\
\text { suhu }\left({ }^{\circ} \mathrm{C}\right)\end{array}$ \\
\hline 1 & 1 & $0-13$ \\
2 & 2 & $13-19$ \\
3 & 3 & $19-25$ \\
4 & 4 & $25-31$ \\
5 & 5 & $31-37$ \\
6 & 6 & $37-43$ \\
\hline
\end{tabular}

\section{Curah Hujan}

Curah hujan merupakan salah satu parameter dalam penyusun kerawanan kebakaran hutan dan lahan. Pembuatan peta curah hujan temporal ini dilakukan dengan menggunakan data CHRS Data Portal pada tahun 2019, dan diklasifikasikan sebagai berikut:

Tabel 4. Klasifikasi Curah Hujan

\begin{tabular}{ccc}
\hline No & Kelas & $\begin{array}{c}\text { Klasifikasi } \\
\text { Curah Hujan } \\
\text { (mm/tahun) }\end{array}$ \\
\hline 1 & 1 & $3096-3186$ \\
2 & 2 & $3185-3274$ \\
3 & 3 & $3274-3363$ \\
4 & 4 & $3363-3452$ \\
\hline
\end{tabular}

7. Peruntukan Lahan
Lahan gambut merupakan lahan yang rentan akan terjadinya kebakaran dalam kondisi cuaca dan suhu tertentu. Keadaan gambut yang kering akibat eksploitasi membuat kebakaran akan cepat merambat. Pada pembuatan peta ini dibuat 4 klasifikasi yaitu lahan non gambut, lahan gambut untuk konservasi, lahan gambut IUPHHK-HTI, dan lahan gambut untuk APL. Menurut Sarwono (2003) sifat lahan gambut tropika yang kurang menguntungkan di antaranya adalah kering tidak balik dan penurunan.

\subsection{Membuat Peta Kerawanan}

Pembuatan peta kerawanan kebakaran ini menggunakan fitur Weighted overlay. Weighted overlay ini berfungsi untuk menganalisis parameter-parameter yang telah ditentukan kemudian disatukan. Sehingga menjadi parameter perwakilan dari 7 parameter yang telah disebutkan sebelumnya.

\section{HASIL DAN PEMBAHASAN}

Dari hasil pengolahan data-data awal dihasilkan 7 peta yang selanjutnya akan diolah menjadi peta kerawanan kebakaran hutan dan lahan berdasarkan bobot parameter yang didapatkan melalui proses Weighted Overlay.

Hasil buffer jalan (Gambar 2) menunjukkan bahwa kawasan Lampung Utara memiliki akses jalan yang sangat baik. Hal ini dapat dilihat bahwa sekitar 95\% kawasan Lampung Utara memiliki akses jalan sejauh $2 \mathrm{Km}$. Sedangkan untuk daerah yang jauh dari akses jalan merupakan kawasan hutan yaitu dengan jarak $10 \mathrm{Km}$ dari jalan utama. Dikarenakan daerah ini merupakan daerah lindung dan karakteristik daerah dihubungkan oleh sungai dan jalan-jalan perkebunan. Bendungan Way Rarem, terletak di Desa Pekurun Kecamatan Abung Barat atau $36 \mathrm{Km}$ dari Kotabumi, atau 113 $\mathrm{Km}$ dari Bandar Lampung.

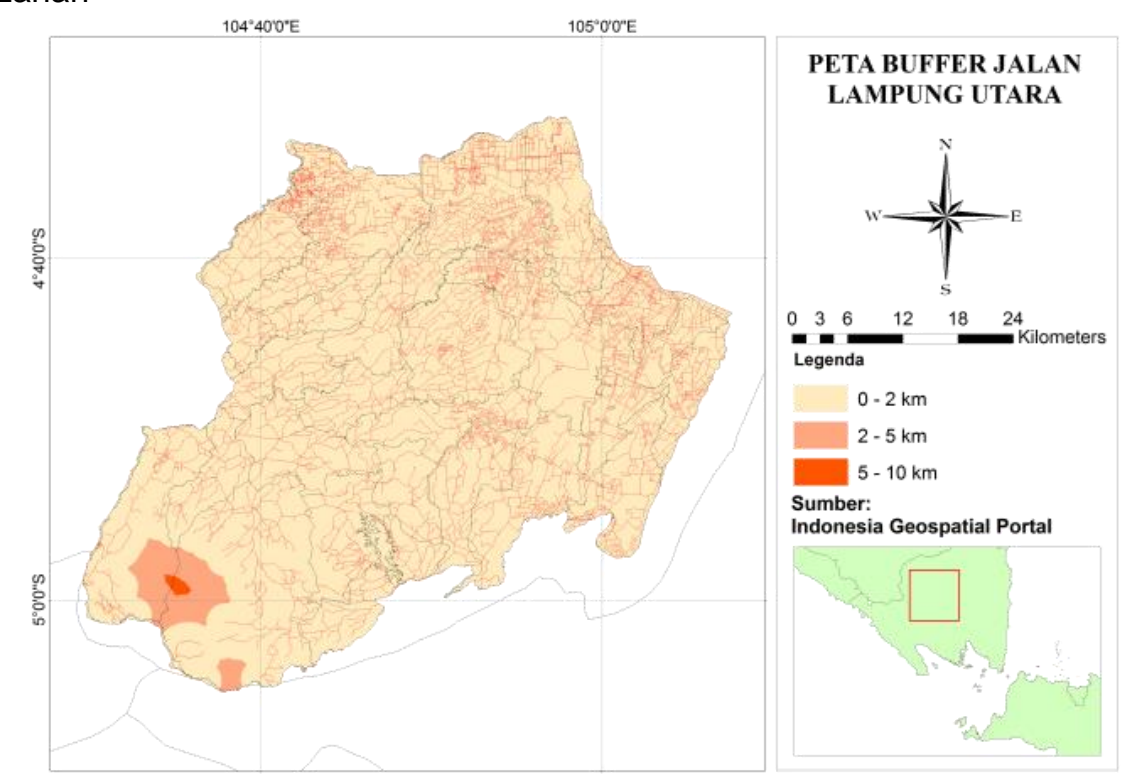

Gambar 2. Peta buffer jalan Kabupaten Lampung Utara yang terbagi atas tiga kelas jarak dengan warna merah merupakan kelas terjauh yaitu $5-10 \mathrm{Km}$. 
Hasil proses buffer sungai (Gambar 3) menunjukkan bahwa lampung utara wilayahnya berada pada lingkup $2 \mathrm{Km}, 5 \mathrm{Km}$ dan $10 \mathrm{Km}$. Hutan dan lahan pada Lampung Utara ini sebagian besar berada pada lingkup $2 \mathrm{Km}$ dari sungai Way

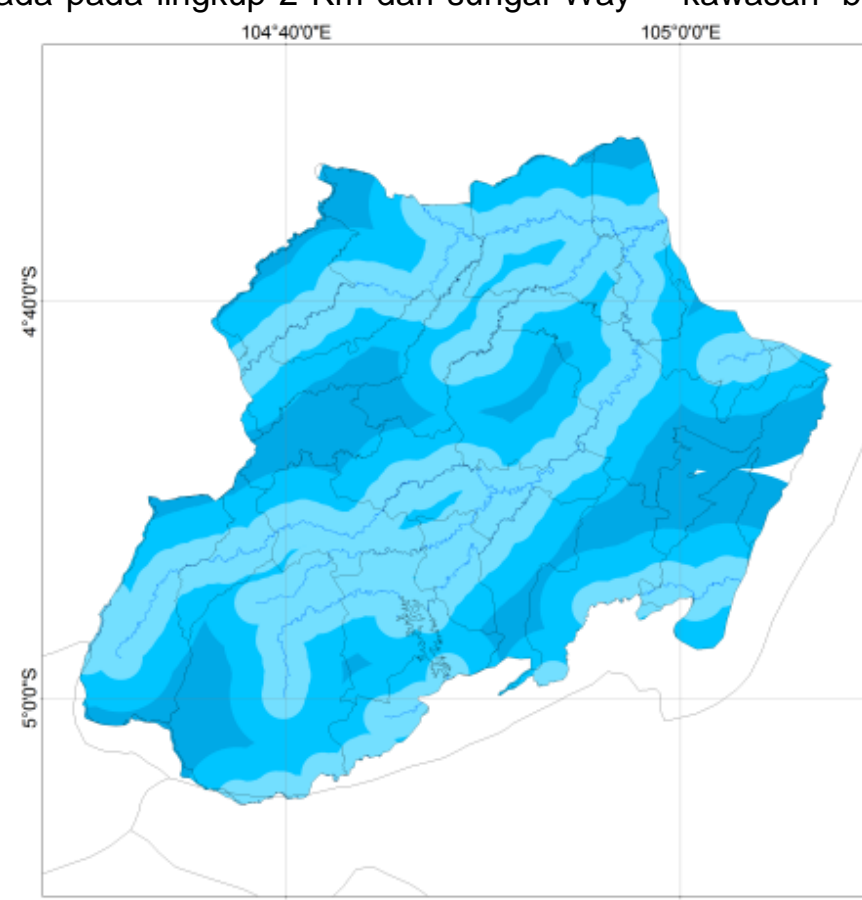

Rarem. Di kawasan Lampung Utara ini memiliki variasi terhadap aksesibilitas sungai. Sekitar 1090 $\mathrm{km}^{2}$ kawasan berada $2 \mathrm{Km}$ dari sungai, $1090 \mathrm{Km}^{2}$ kawasan berada $5 \mathrm{Km}$ dari sungai, dan $20 \%$ kawasan berada $10 \mathrm{Km}$ dari sungai $545 \mathrm{Km}^{2}$. $5^{5} 0^{\circ} 0^{\circ} \mathrm{E}$

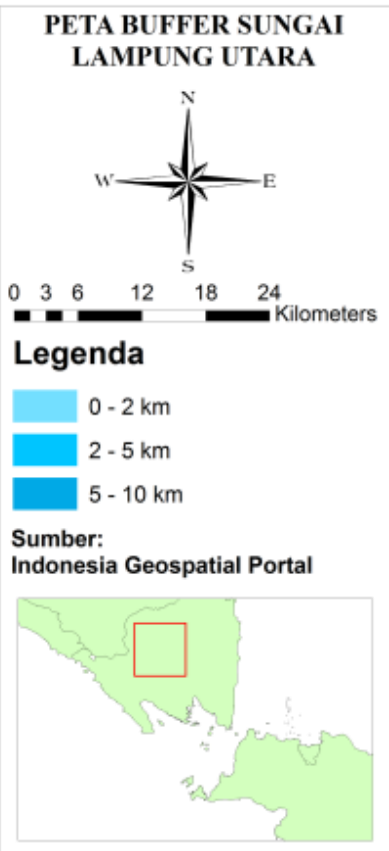

Gambar 3. Peta buffer sungai Kabupaten Lampung Utara yang terbagi atas tiga kelas jarak dengan warna biru tua merupakan kelas terjauh yaitu 5-10 Km.

Hasil klasifikasi kerawanan kebakaran berdasarkan tutupan lahan (Gambar 4), terlihat bahwa kawasan Lampung Utara memiliki tingkat kerawanan sedang atau kelas kerawanan 2 yaitu dengan luas $2317 \mathrm{~km}^{2}$. Tingkat kerawanan ter- sebut merupakan area perkebunan yang diurus oleh warga setempat. Kemudian kelas kerawanan 4 memiliki luas $164 \mathrm{~km}^{2}$, kelas kerawanan 3 memiliki luas $109 \mathrm{~km}^{2}$, dan kelas kerawanan $1 \mathrm{me}$ miliki luas $136 \mathrm{~km}^{2}$.

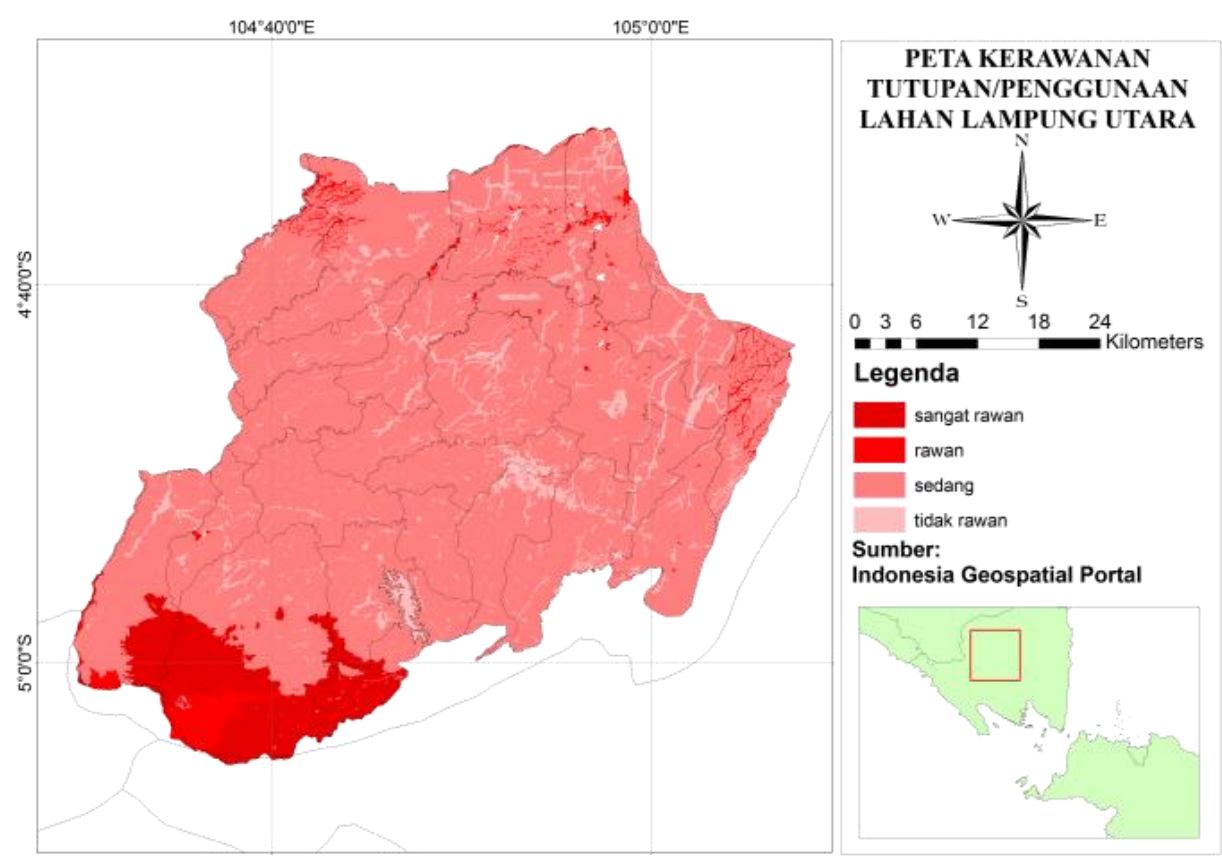

Gambar 4. Peta Kerawanan tutupan penggunaan lahan Kabupaten Lampung Utara yang dibagi menjadi empat kelas. 
Hasil pengolahan data hotspot pada tahun 2019 (Gambar 5) didapatkan 4 klasifikasi kepadatan hotspot. yaitu sangat jarang, sedang, padat, dan sangat padat. Kawasan Lampung Utara yang memiliki hotspot tertinggi yaitu pada daerah Sungkai Selatan, Kotabumi, dan Bunga Mayang.
Pada ketiga daerah tersebut dapat dikategorikan memiliki kerawanan kebakaran kelas 3 berdasarkan kepadatan hotspot. Dan untuk sebagian besar kawasan Lampung Utara memiliki tingkat kepadatan hotspot kelas 1 yaitu sangat jarang.

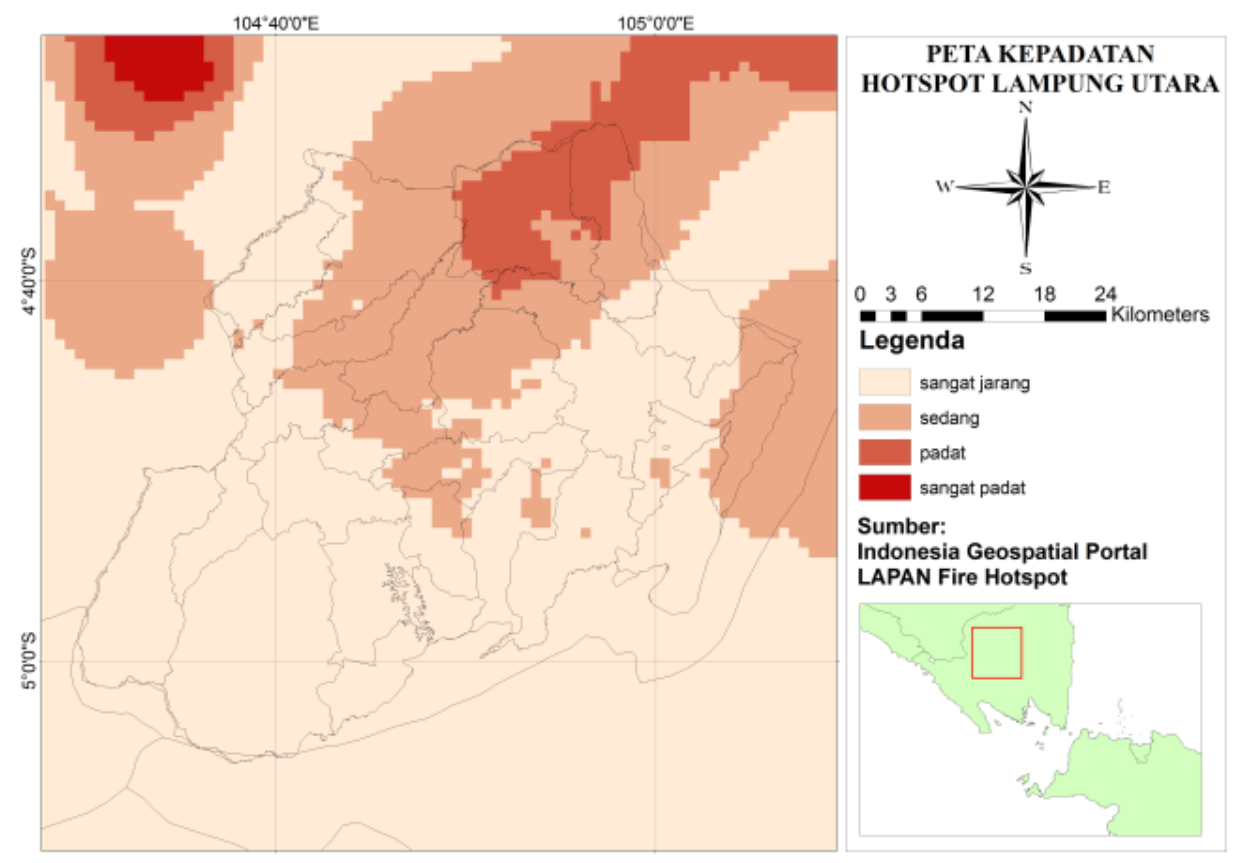

Gambar 5. Peta kepadatan hotspot Lampung Utara yang dibagi menjadi empat kelas mulai dari sangat jarang sampai sangat padat.

Berdasarkan peta perizinan lahan gambut (Gambar 6), didapatkan bahwa mayoritas lahan Lampung Utara merupakan wilayah non gambut yaitu berkisar $2317 \mathrm{~km}^{2}$. Pada lahan mayoritas ini ditutupi oleh perkebunan. Dan untuk wilayah paling rawan (kelas 4) yaitu lahan gambut dengan pengelolaan APL seluas $109 \mathrm{~km}^{2}$.

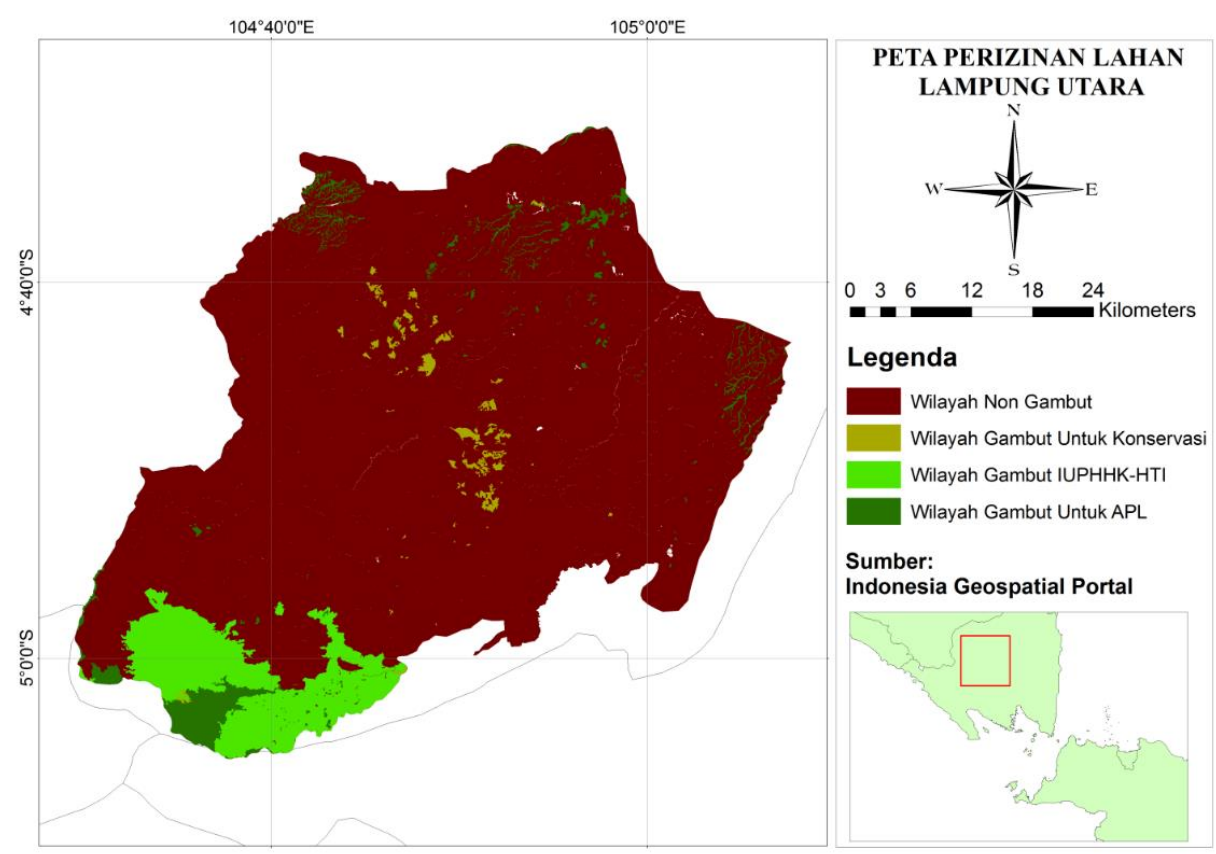

Gambar 6. Peta perizinan lahan Kabupaten Lampung Utara yang dibagi menjadi empat kelas wilayah gambut dan non gambut. 


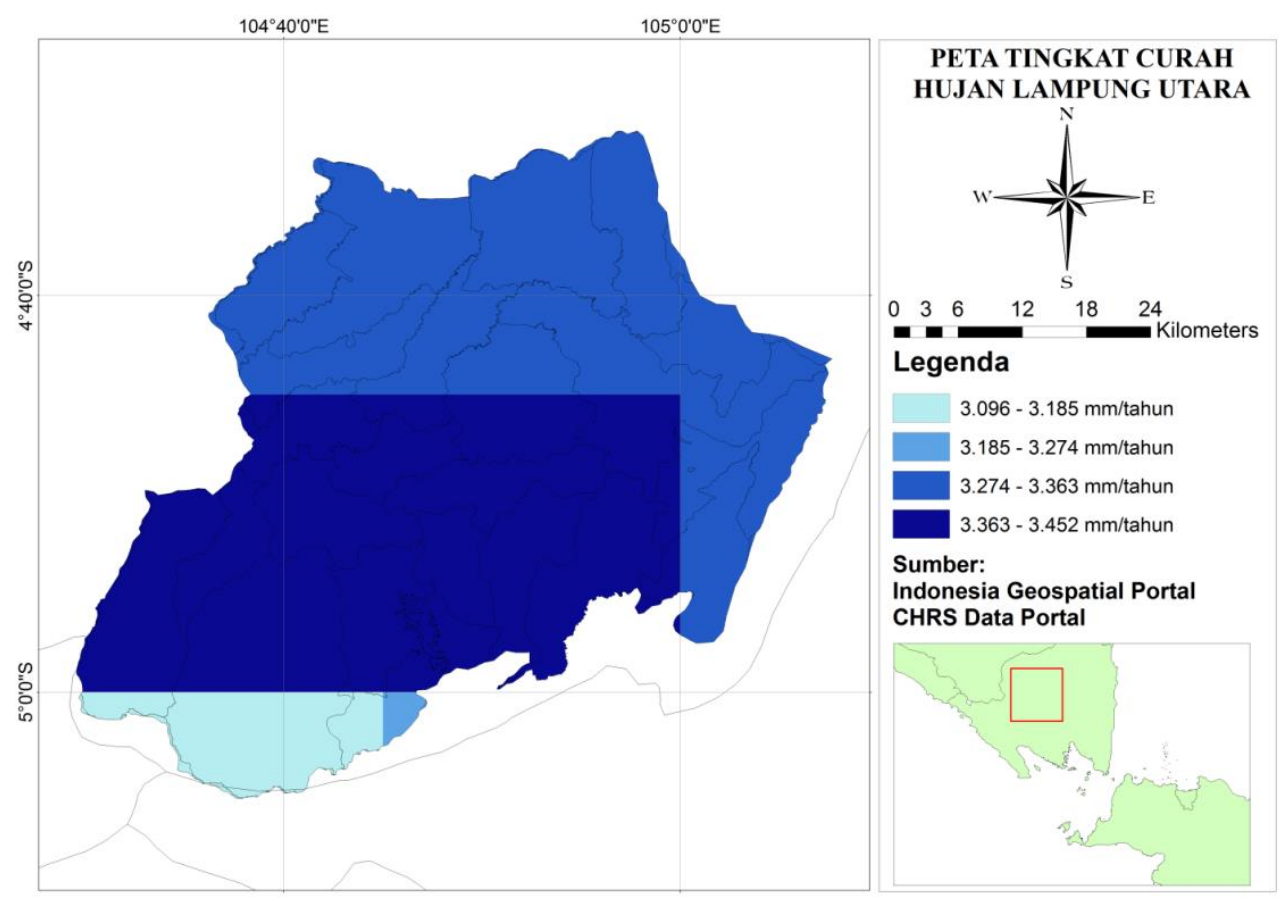

Gambar 7. Peta curah hujan Lampung Utara

Hasil pembuatan peta curah hujan (Gambar 7) didapatkan 4 klasifikasi yaitu 3096 - 3186 $\mathrm{mm} / \mathrm{tahun}, 3185$ - $3274 \mathrm{~mm} / \mathrm{tahun}, 3274-3363$ $\mathrm{mm} / \mathrm{tahun}$, dan 3363 - $3452 \mathrm{~mm} / \mathrm{tahun}$. Pada peta dapat dilihat bahwa daerah yang memiliki curah hujan yaitu pada kawasan hutan. Sedangkan untuk kawasan yang memiliki intensitas hujan tertinggi berada di pemukiman warga dan perkebunan.

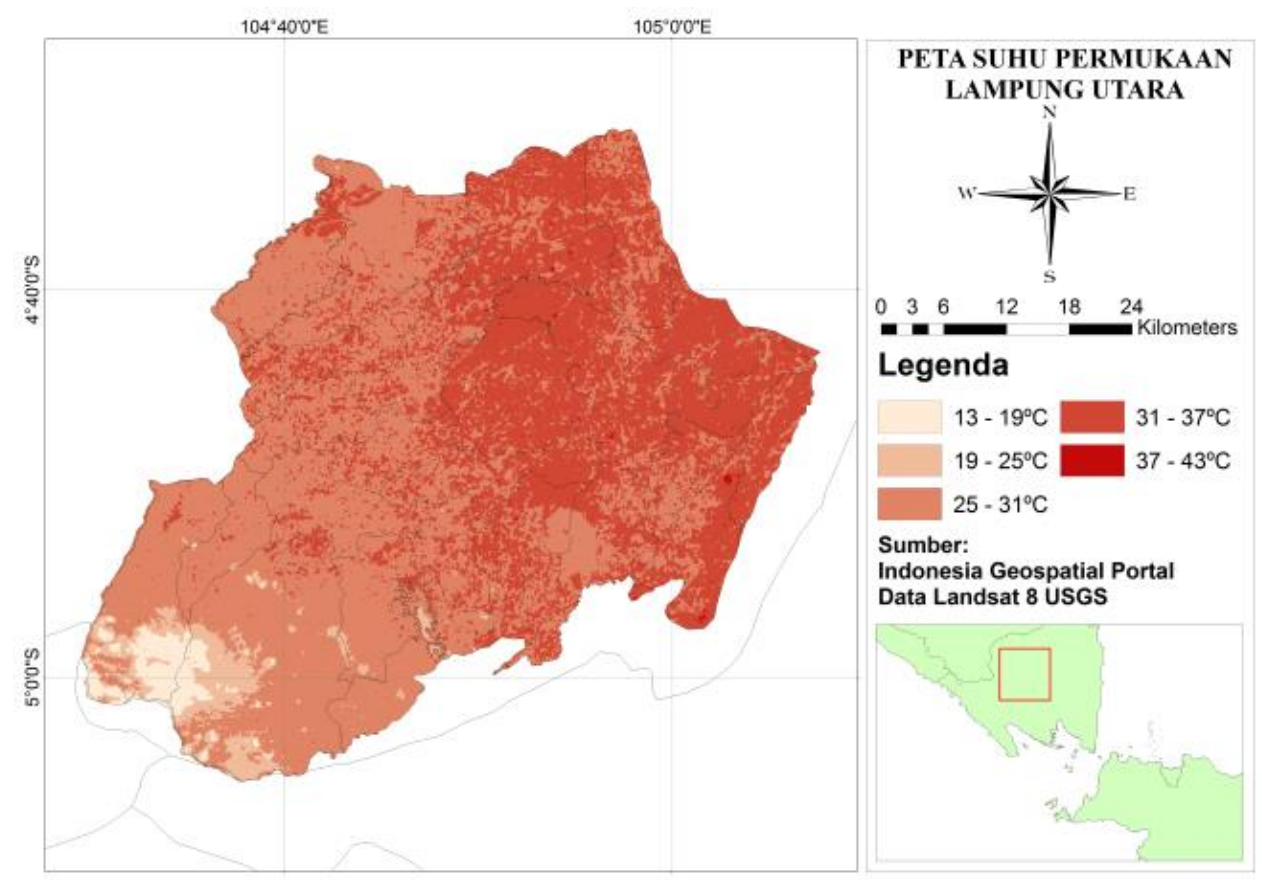

Gambar 8. Peta suhu permukaan Lampung Utara 


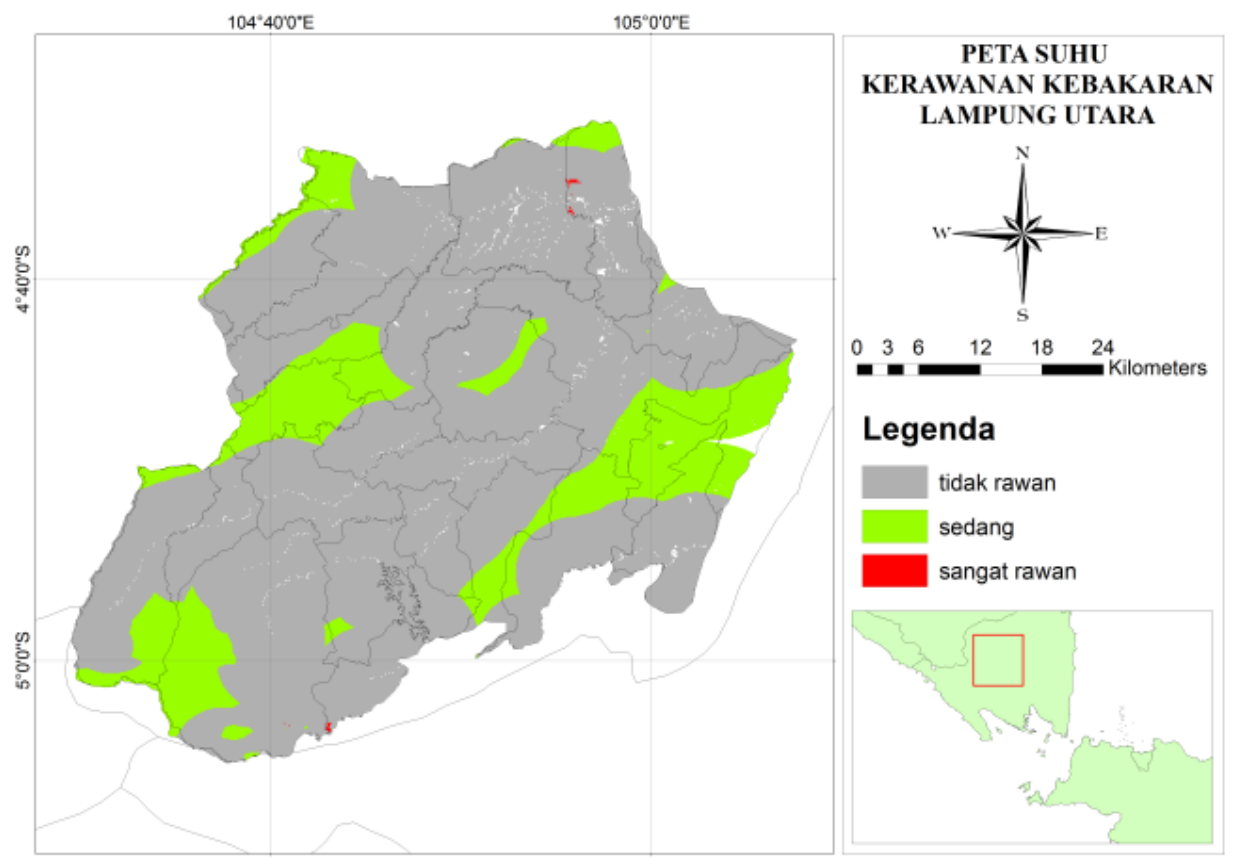

Gambar 9. Peta Kerawanan Kebakaran Lampung Utara

\section{KESIMPULAN}

Pembuatan peta kerawanan yang menggunakan 7 parameter yaitu curah hujan, hotspot, buffer sungai, buffer jalan, suhu permukaan, lahan gambut, dan tutupan lahan didapatkan sebuah peta kerawanan kebakaran dengan 3 tingkat kerawanan yaitu tidak rawan, sedang, dan sangat rawan. Pada daerah tidak rawan ini merupakan daerah pemukiman warga dan memiliki aksesibilitas sungai yang dekat. Hal lain yang mempengaruhi yaitu tingkat kepadatan hotspot kawasan ini dikategorikan tidak padat. Sehingga pada kawasan Lampung Utara ini dikategorikan tidak rawan terhadap kebakaran.

\section{UCAPAN TERIMA KASIH}

Penulis mengucapkan terima kasih kepada dosen mata kuliah citra satelit yang telah membimbing kami untuk bekerja sama dalam penelitian ini.

\section{DAFTAR PUSTAKA}

BNPB. (2016). Evaluasi Penanggulangan Bencana 2015 dan Prediksi Bencana 2016. Jakarta: BNPB.

Cahyadi, A. I. B., Suprayogi, A., \& Amarrohman, F. J. (2018). Penentuan lokasi potensial pengembangan kawasan industri menggunakan sistem informasi geografis di Kabupaten Sukoharjo. Jurnal Geodesi Undip 7(1): 163-171.

Danny, W. (2001). Interaksi Ekologi dan Sosial Ekonomi Dengan Kebakaran di Hutan Propinsi Kalimantan Timur Indonesia. Paper Presentasi pada Pusdiklat Kehutanan. Bogor.
Delarizka, A. (2016). Analisis Fenomena Pulau Bahang (Urban Heat Island) di Kota Semarang Berdasarkan Hubungan Antara Perubahan Tutupan Lahan Dengan Suhu Permukaan Menggunakan Citra Multi Temporal Landsat. Semarang: Jurnal Geodesi UNDIP, Vol. 5, No. 4

Endarmiyati. (2009). Zonasi kerawanan kebakaran hutan dan lahan berserta strategi pencegahannya di Kabupaten Siak provinsi Riau. Yogyakarta: Sekolah Pascasarjana UGM

Heil, A., Langman, B., \& Aldrian, E. (2007). Indonesia Peat and Vegetation Fire Emissions: Study on Factor Influenching Large-Scale Smoke Haze Pollution Using a Regional Athmospheric Chemistry Model. Mitigation and Adaptation Strategies for Global Change, Vol. 12, No. 1, hal. 113-133.

Hermawan, E. (2010). Pengelompokkan Pola Curah Hujan Yang Terjadi Di Beberapa Kawasan P. Sumatera Berbasis Hasil Analisis Teknik Spektral. Lembaga Penerbangan dan Antariksa (LAPAN).

KLHK. (2016). Rekapitulasi Luas Kebakaran Hutan dan Lahan (ha) Per Provinsi di Indonesia Tahun 2011-2016. Jakarta: KLHK.

Nugraha, W. S., Subiyanto, S., \& Wijaya, A. P. (2015). Penentuan lokasi potensial untuk pengembangan kawasan industri menggunakan sistem informasi geografis di Kabupaten Boyolali. Jurnal Geodesi Undip 4(1): 194-202.

Purwanto, A. (2019). Pemanfaatan Sistem Informasi Geografis Untuk Menentukan Lokasi Potensial Pengembangan Kawasan 
Industri Di Kabupaten Pati. Jurnal Tanah dan Sumberdaya Lahan.

Rianto, I. B., \& Santoso, E. B. (2018). Penentuan lokasi kawasan industri tekstil terpadu di Kabupaten Majalengka. Jurnal Teknik ITS 7(1): 19-22.

Sahardjo, B. H. (2002). Strategi Pengendalian Kebakaran Hutan di Indonesia. Di dalam: Workshop Nasional Strategi Pengendalian Kebakaran Hutan dan Lahan menghadapi Ancaman Bahaya El-Nino 2002. Bogor: IPB dan Kementrian Lingkungan Hidup.

Sarwono. (2003). Klasifikasi Tanah dan Pedogenesis. Akademik Pressindo. Jakarta.

Suhendri, S., \& Priyo, E. (2017). Penguatan Kelembagaan Dalam Pencegahan dan Pengendalian Kebakaran Hutan dan Lahan di Kabupaten Muaro Jambi Provinsi Jambi. Jurnal of Govermance and Public Policy, 4(1), 174-204
Tucker, C. J. (1979). Red and Photographic Infrared Linear Combination for Monitoring Vegetation. Remote Sensing of Environment, Vol. 43, No. 2, hal. 333-337.

Tukidi. (2010). Karakter Curah Hujan di Indonesia. Jurnal Geografi, 7(2), 136-145.

USGS. (2002). Persamaan Nilai Suhu Kecerahan. Identifikasi Neraca Energi Untuk Deskripsi Potensi Kekeringan Dengan Data Landsat TM.

USGS. (2015). LANDSAT 8 (L8) DATA USERS HANDBOOK. Department of the Interior U.S. Geological Survey.

Wahyunto, Masganti, Dariah, A., Nurhayati, \& Yusuf, R. (2014). Karakteristik dan Potensi Pemanfaatan Lahan Gambut Terdegradasi di Provinsi Riau. Jurnal Sumber Daya Lahan, 8, 59-66. 